Humaniora. Czasopismo Internetowe

$\mathrm{Nr} 3(35) / 2021,55.73-91$

\author{
TOMASZ GRUSZCZYK \\ Uniwersytet Śląski w Katowicach \\ Wydział Humanistyczny \\ Instytut Nauk o Kulturze i Studiów Interdyscyplinarnych \\ e-mail: tomasz.gruszczyk@us.edu.pl \\ ORCID: 0000-0001-5821-3250 \\ DOI: https://doi.org/10.14746/h.2021.3.5
}

\title{
Ciało, gest, literatura
}

Mowa jest gestem, a jej znaczenie światem.

Maurice Merleau-Ponty ${ }^{1}$

Pisanie pisze nas.

John M. Coetzee ${ }^{2}$

\begin{abstract}
As Maurice Merleau-Ponty wrote, the experience of the body, the somatic experience and the gesture as an act of expression bring into being both the sense of things that are being interacted with and the sense of existence of which the body is a vehicle. If so, then the verbal expression, creativity, literature - apart from the fact that it is (most often) a representation of things (and thoughts) that are already anchored in culture and create its universe - can be an individual event of a similar nature and course: becoming, creating, bringing out the subject-body in writing and in what's being written. The works of Stanisław Czycz serve as an example of such literature-gesture. They have specific characteristics of autobiographical and autocreational writing, and also take up the problem of experiencing the body and corporeality. However, they are analyzed here as autoteleological work - as a gesture of a body that is being created and a body that is creating its own sense.
\end{abstract}

Keywords: Maurice Merleau-Ponty, body, literature as gesture, Stanisław Czycz, autocreation

${ }^{1}$ M. Merleau-Ponty, Fenomenologia percepcji, tłum. M. Kowalska i J. Migasiński, posł. J. Migasiński, Fundacja Aletheia, Warszawa 2001, s. 205.

2 J.M. Coetzee, Doubling the Point: Essays and Interviews, cyt. za: D. Attridge, Jednostkowość literatury, tłum. P. Mościcki, Towarzystwo Autorów i Wydawców Prac Naukowych Universitas, Kraków 2007, s. 42. 
C iała piszące i pisane, ciała czytające i czytane - to pełnoprawni obywatele republiki literatury ${ }^{3}$. Pełnoprawni, acz o różnym sposobie istnienia, stopniu obecności i rozpoznawalności, wreszcie rozlokowani w różnych jej rejonach oraz na biegunowo przeciwnych pozycjach komunikacji literackiej.

Pisząc „ciało” - trzeba to wyraźnie zaznaczyć - nie sprowadzam jednak podmiotów (czy też aktantów), którymi tym słowem określam, wyłącznie do tego, co materialne i sensualne, do fizycznego i fizjologicznego wymiaru istnienia. Takie obrazy podsuwa nam zdrowy rozsądek, potoczne wyobrażenie, a nawet sam język: ciało jako to, co najbardziej namacalne i własne dla jednostki - na przykład ciało, które mnie boli. Wizerunek ten dopełniają oparte na myśleniu dualistycznym (którego zalążki odnajdujemy już u presokratyków) nowożytne koncepcje cielesności. Bodaj pełny wyraz dał mu już Kartezjusz, wyraźnie rozgraniczając materię od umysłu, czucia i podmiotowości. Ciało miało być surową (nierozumną, bezrefleksyjną oraz bierną) materialnością, organizmem o cechach sprawnego mechanizmu-narzędzia, pojemnikiem dla duszy czy duchowego wnętrza, res extensa; umysł zaś - res cogitans - myślą, wolnością i aktywnością ${ }^{4}$.

Wszelkie dualne koncepcje jednostki złożonej z duszy i ciała jako czegoś wyłącznie materialnego - rzeczy bądź też przedmiotu pozostającego w polu widzenia wyabstrahowanej ze świata i życia świadomości - musimy w tym miejscu nie tyle porzucić, ile uzupełnić o inne propozycje. W przeciwnym razie początkowe zdanie i pojęcie ciała piszącego, pisanego i czytającego sprowadzałoby się do skonstatowania banalnego faktu, że czyjaś ręka dzierży pióro lub stuka w klawisze, stawia znaki i formuje za ich pomocą jakiś wizerunek ciała - zgodny bądź niezgodny z kanonami myślenia i mówienia o cielesności pewnej uwarunkowanej kulturowo społeczności - następnie zaś ukończone dzieło trafia do rąk czytelnika, który wodzi wzrokiem po znakach, przerzuca stronice, odkłada tom na półkę. Ciało w tym trybie myślenia pozostaje rzeczą, przedmiotem-narzędziem dla podejmującego aktywność, działanie, twórczego umysłu, woli. Ale staje się też znakiem-rzeczą; reprezentuje w tekście pewne zbiorowe (kulturowe) praktyki i dyskursy, które poddają się egzegezie:

${ }^{3}$ Przywołuję tu określenie Pascale Casanovy, lecz nieco je poszerzam. Zob. P. Casanova, Światowa republika literatury, tłum E. Gałuszka, A. Turczyn, Wydawnictwo Uniwersytetu Jagiellońskiego, Kraków 2017.

${ }^{4}$ Ostatnią bodaj „fazą” tego myślenia była propozycja Edmunda Husserla: w obrębie psychofizycznej całości (monady) ciało to i fizyczna bryła, czysta materialność (ciało-Körper oglądane z zewnątrz), i pole wrażeń (ciało-Leib doświadczane od strony wewnętrznej). Zob. E. Husserl, Idee czystej fenomenologii i fenomenologicznej filozofii, t. II, tłum. D. Gierulanka, PWN, Warszawa 1974. 
[...] obiektem badań jest dzisiaj bowiem ciało uzależnione od wielu systemów, opisane przez wiele dyskursów jednocześnie, ciało wykreowane przez dyskurs medyczny, polityczny, religijny, przez konkretne ideologie; uzależnione od systemów społecznych i systemów władzy, ujmowane przez konstrukty płci właściwe dla danych społeczności (i to w wymiarze zarówno historycznym, jak i geograficznym) ${ }^{5}$.

Nie o takim (albo: nie tylko o takim) ciele chcę tutaj mówić. Raczej rezerwuję to pojęcie do określenia ostoi istnienia i osadzenia w bycie ludzkiej podmiotowości. Innymi słowy: ciało wieść nas będzie ku czasowości i konkretności, jednostkowości i partykularności, sytuacyjności i akcydentalności, wreszcie przeżywaniu - bycia i poznania, pisania i czytania.

\section{2.}

Ciało jest wehikułem bycia w świecie, a mieć ciało to dla żyjącej istoty wiązać się z określonym środowiskiem, utożsamiać się z pewnymi projektami i stale się w nie angażować ${ }^{6}$ - zanotował Maurice Merlau-Ponty w wydanej po raz pierwszy przez Gallimarda w 1945 roku Fenomenologii percepcji.

Ta i kolejne publikacje ${ }^{7}$, w których silnie zmetaforyzowany, obfitujący w retoryczne i poetyckie tropy filozoficzny dyskurs konsekwentnie próbuje przekroczyć dualizm duszy i ciała ${ }^{8}$, znieść opozycję bios i logos (Kartezjusz i Immanuel Kant są tu głównymi negatywnymi punktami odniesienia), opozycję empiryzmu i intelektualizmu, uniknąć pułapek tak naturalizmu, jak idealizmu, wreszcie efektownie i efektywnie buduje koncepcję podmiotu wcielonego na podstawie dialektyki fenomenologii Edmunda Husserla i analityki jestestwa Martina Heideggera ${ }^{9}$, stanowią do dziś - z tych właśnie powodów - inspirującą lekturę i ważne odniesienie dla badaczek i badaczy w różnych, nieraz znacznie od siebie oddalonych obszarach nauk humanistycznych czy społecznych ${ }^{10}$.

${ }^{5}$ A. Łebkowska, Somatopoetyka, w: Kulturowa teoria literatury 2. Poetyki, problematyki, interpretacje, red. T. Walas, R. Nycz, Towarzystwo Autorów i Wydawców Prac Naukowych Universitas, Kraków 2012, s. 107.

${ }^{6}$ M. Merleau-Ponty, Fenomenologia percepcji, s. 100.

${ }^{7}$ Do najważniejszych należy jeszcze zaliczyć (przetłumaczone na język polski - rok wydania w nawiasie): Proza świata. Eseje o mowie (1976), Widzialne i niewidzialne (1996), Oko i umysł: szkice o malarstwie (1996), Pochwała filozofii (2003).

${ }^{8}$ Lub „można by ostrożniej powiedzieć, że filozofia francuskiego autora skierowana była przeciwko wszelkim próbom rozpatrywania relacji dusza-ciało w kategoriach pewnej odmiany dualizmu”. M. Drwięga, O działaniu i relacji dusza-ciało w filozofii Maurice’a Merleau-Ponty’ego w pięćdziesiątq rocznicę śmierci, „Kwartalnik Filozoficzny” 2011, t. XXXIX, z. 3, s. 10.

9 Już w Przedmowie do Fenomenologii percepcji pada zdanie: „In-der-Welt-Sein Heideggera ukazuje się dopiero na tle fenomenologicznej redukcji”. M. Merleau-Ponty, Fenomenologia percepcji, s. 12.

${ }^{10}$ Pisarstwo to jeśli nie funduje (w mocnym sensie tego słowa), to współtworzy propozycje niektórych odmian kognitywistyki (zob. M. Pokropski, Ciało. Od fenomenologii do kognitywi- 
Próbkę tego czym jest i o czym jest to myślenie-pisanie przynosi cytowany wyżej fragment. Mowa w nim o tym, że ciało jest właściwym istocie żyjącej sposobem obecności w świecie. Obecności tej nie sposób jednak sprowadzić do trwania, istnienia, zjawiania się; nagromadzenie czasowników (wiązać, utożsamiać, angażować się) wskazuje na uczestnictwo w świecie, wydanie jednostki światu (w czym wyraźnie wybrzmiewają echa filozofii egzystencji). Tyle tylko, co Merleau-Ponty będzie zaznaczał wielokrotnie, że ów angaż w bycie ma koniecznie dialektyczny (a może nawet dialogiczny) charakter aktu-responsu. Obecność w świecie dana jednostce w i za pośrednictwem ciała (ciało jako wehikuł) to nierozerwalna i niezbywalna „relacja wzajemnego wspomagania i zależności”11 - tego właśnie ciała i tego właśnie świata. Istotne, że - podobnie jak w Byciu i czasie Heideggera - nad poznanie przedkłada się tu ontologiczny wymiar bycia-w-świecie. Precyzyjniej: istnienie świata jako przedmiotu poznania ma być wtórne wobec pierwotnej dostępności świata danej dzięki ciału, poprzez ciało i w jego przeżywaniu. Merleau-Ponty w innym miejscu wyrazi tę relację w mowie figuratywnej. Napisze: „świat przylega do mojego ciała jak tunika Nessosa”12.

Muszę zaznaczyć to wyraźnie w tym miejscu: nie jest moim celem szczegółowe odtwarzanie całej drogi myślowej filozofa, która ma (podobnie jak u Husserla) przywieść z powrotem do rzeczy i to spotkanie człowieka z rzeczą, bytem, uchwycić w siatkę mniej lub bardziej precyzyjnych pojęć. Tego rodzaju wysiłek podejmowano już wielokrotnie, z doskonałym zresztą skutkiem ${ }^{13}$. Mnie interesować będzie zaledwie niewielki odcinek tej drogi i możliwe (do pomyślenia i wyłożenia) jej rozgałęzienia: charakter relacji jednostkowego podmiotu z ciałem i napotykanym bytem oraz to, gdzie w tej relacji lokuje się mowa, ekspresja, literatura. I wreszcie - jakie to może mieć znaczenie dla doświadczenia literackiego.

styki, „Przegląd Filozoficzno-Literacki” 2011, nr 4), filozofii korporalnej (zob. E. Grosz, Volatile Bodies: Toward a Corporeal Feminism, Indiana University Press, Bloomington 1994; E. Hyży, Kobieta, ciało, tożsamość. Teorie podmiotu w filozofii feministycznej końca XX wieku, Towarzystwo Autorów i Wydawców Prac Naukowych Universitas, Kraków 2003) czy ekofenomenologii (zob. D. Abram, The Spell of the Sensuous: Perception and Language in a More-than Human World, Pantheon Books, New York 1996). Dostrzega się w nim nawet zarys czy zaczyn filozofii różnicy Michela Foucaulta, Emmanuela Lévinasa, Jean-Françoisa Lyotarda i Jacques’a Derridy. Zob. M. Kwietniewska, Maurice Merleau-Ponty: u zarania filozofii różnicy we Francji, „Hybris” 2016, nr 34.

${ }^{11}$ M. Gołębiewska, Sensotwórcza rola ciała w samopoznaniu według Maurice’a Merleau-Ponty'ego, „Teksty Drugie” 2004, nr 1-2, s. 239.

${ }^{12}$ M. Merleau-Ponty, Obecni w słowie, tłum. J. Skoczylas, w: idem, Proza świata. Eseje o mowie, Czytelnik, Warszawa 1976, s. 69.

${ }^{13}$ Na uwagę zasługują zwłaszcza dwie monografie: J. Migasiński, Merleau-Ponty, Wiedza Powszechna, Warszawa 1995; M. Maciejczak, Świat według ciała w Fenomenologii percepcji Merleau-Ponty'ego, IFiS PAN, Warszawa 2001. 
Najpierw więc jest ciało. Nie wyabstrahowana świadomość (podmiot poznający jako zdystansowany widz spektaklu świata), dla której byt, który ona sobie przedstawia, jest wynikiem jej własnej pracy, lecz cielesne zakorzenienie w świecie i zmysłowo-intelektualna z nim interakcja ${ }^{14}$. Czy należy z tego wyciągać wniosek, że ciało - jak je rozumie Merleau-Ponty - jest zaledwie polem dla nieusystematyzowanych wrażeń, że jego funkcja sprowadza się zaledwie do receptywności? „Wiązanie się”, ,utożsamianie się”, ,,angażowanie się” zdecydowanie temu przeczą. Wyrażają bowiem aktywne ustosunkowywanie się - ale nie do rzeczy, świata/bytu, który oto się przedstawia - lecz do „środowiska” i „projektu” tworzących „sytuację”. Czym ona jest? Przede wszystkim podmiotowym uwikłaniem w fizyczność i dziejowość. Ale nie tylko. „Sytuacją” nazywa też filozof potencjalność sensu, który z jednej strony udziela się jednostce, z drugiej zaś - oczekuje na wydobycie, wyzwolenie:

Ciało [...] jest również tym, co mnie na świat otwiera i wprowadza mnie w sytuację. [...] Ciało własne [...] jest samym ruchem ekspresji, tym, co rzutuje znaczenia na zewnątrz, udzielając im miejsca, tym, co sprawia, że zaczynają one istnieć jak rzeczy, pod naszymi rękami, przed naszymi oczami ${ }^{15}$.

Ekspresja ciała - odruchy, gesty, ale również, jak się okaże, mowa - ma być więc usensownianiem świata i relacji z nim. Rzecz jasna, ciało nie jest jeszcze podmiotem poznania w sensie ścisłym, niemniej jednak doznawaniu wrażeń towarzyszy już ich sensotwórcze opracowywanie (jeszcze na poziomie przedrefleksyjnym). Świadectwem tego jest szczegółowo omawiana przez Merleau-Ponty’ego motoryka ciała: ruch ku rzeczy jest ruchem ku jej znaczeniu - dla ciała i ze względu na ciało w pewnej sytuacji. To ciało własne otwiera świat dla subiectum, a swą ekspresją, umiejętnościami wywołuje określone znaczenia i sensy, które już zawczasu w świecie się zawierają - odkładają, nawarstwiają. Gest, mimo że niemy, woła, nawołuje i wywołuje. Uruchamia dialog, w którym „przywołany świat zyskuje językową postać. Tam właśnie, w nim, zamieszkuje człowiek”16.

Jako się rzekło, samo słowo również jest gestem, choć „gestem szczególnym” ${ }^{17}$. Dlaczego szczególnym? Jeśli „gest naturalny” czy ekspresja ciała wywołuje, sy-

14 „Umysł, który postrzega, jest umysłem wcielonym. [...] Ciało własne [...] jest naszym punktem widzenia świata, miejscem, w którym umysł uwikłał się w pewną sytuację fizyczną i dziejową”. M. Merleau-Ponty, Wyznanie wiary, tłum. S. Cichowicz, w: idem, Proza świata..., ss. 25, 27.

${ }^{15}$ M. Merleau-Ponty, Fenomenologia percepcji, ss. 185-186 i 166.

${ }^{16}$ K. Gurczyńska-Sady, Człowiek jako słowo i ciało. W poszukiwaniu nowej koncepcji podmiotu, Towarzystwo Autorów i Wydawców Prac Naukowych Universitas, Kraków 2013, s. 164.

${ }^{17}$ M. Merleau-Ponty, Obecni w słowie, s. 72. 
gnalizuje, wskazuje czy też powołuje znaczenie, to mowa, akt słowny czyni coś więcej: „musi sprawić, by znaczenie to powstało, jest zatem dla niego istotne, by wykroczyć poza siebie jako gest; jest gestem, który jako gest sam siebie znosi, by wykroczyć poza siebie ku znaczeniu”18. Mowa jako gest, który sam siebie znosi? Pozbawiając mowę funkcji gestu - funkcji wskazywania lub oznaczania przedmiotu lub myśli - Merleau-Ponty uwydatnia jej aspekt... cielesny. Pisze bowiem, że jest ona „samą obecnością tej myśli w świecie zmysłowym, [...] jej emblematem lub jej ciałem”19. Myśl, znaczenie niemal dosłownie rodzi się w mowie jako operacji ekspresji: „zaczyna żyć w słownym organizmie” i przejmuje rolę nowego organu zmysłowego - „otwiera nowe pole lub nowy wymiar przed naszym doświadczeniem”20.

Zatrzymajmy się w tym miejscu: to punkt węzłowy tej propozycji, punkt, który otwiera pytania o możliwość pomyślenia literatury jako zdarzenia, w które zaangażowane są ciała piszące i ciała czytające. Trzeba tu jednak poczynić jedną uwagę - dopowiedzieć, czym jest „mowa” w słowniku filozofa. To pozwoli doprecyzować dotychczasowe ustalenia i zawęzić pole zjawisk, do którego wspomniane pytania mogłyby się odnosić.

Po pierwsze więc, mowa jest „zjawiskiem polegającym na tym, że ktoś mówi coś do kogoś o czymś”21. Innymi słowy: pojęcie to nie obejmuje języka jako systemu oderwanego od aktu słownego, lecz za każdym razem wskazuje na ten właśnie akt.

Po drugie, w obrębie tak zarysowanej mowy filozof wyróżnia „mowę mówioną” (parole parlée) i „mowę mówiącą” (parole parlante). W tej pierwszej aktualizują się sensy i znaczenia obecne już w kulturze, przyjęte i podzielane przez daną społeczność w jakimś momencie dziejowym. Można to powiedzieć jeszcze inaczej: „manifestuje się [w niej - T.G.] to, co wspólnotowe w podmiocie”22. „Mowa mówiąca” natomiast, ekspresja spontanicznego ciała, ma być nadawaniem przez jednostkę znaczenia swemu światu - sytuacji, w którą jest już zaangażowana. To czysty ruch ekspresji, ruch, którego wektor skierowany jest w stronę tego, co inne, co jeszcze nieobecne, co jeszcze nie przyoblekło się w ciało myśli i sensu. Ekspresja ta nie jest napędzana żadną wyraźną myślą, lecz rodzącą się intencją znaczącą, „pewnym brakiem, który próbuje się wypełnić” ${ }^{23}$. Podejmowanie tej intencji, spełnianie jej owocuje twórczością, literaturą, która „zaszczepia sens tam, gdzie go nie było, [...] nie ograniczając się do chwili swego trwania otwiera nowe pole, zapoczątkowuje

18 Ibidem, s. 73.

19 M. Merleau-Ponty, Fenomenologia percepcji, s. 203.

20 Ibidem. Dwie strony dalej autor dopowiada: „Myśl nie jest niczym wewnętrznym, nie istnieje poza światem i poza słowami. Tym, co wprowadza nas w błąd, co każe nam wierzyć w myślenie istniejące dla siebie przed ekspresją, są już ukonstytuowane i już wyrażone myśli, które możemy przywołać w milczeniu i które dają nam złudzenie myślenia wewnętrznego”.

21 S. Cichowicz, Poezja świata, w: M. Merleau-Ponty, Proza świata..., s. 12.

22 M. Gołębiewska, Sensotwórcza rola ciała..., s. 245.

23 M. Merleau-Ponty, Fenomenologia percepcji, s. 205. 
nowy porządek, wprowadza instytucję bądź tradycję²4. Twórczość jest gestem dwuznacznym: przerzuca pomost między tym, co jednostkowe a tym, co wspólne, powszechne, ale też „splata sens - z naszym życiem”25.

Ta ostatnia kwestia jest dla nas bodaj najważniejsza. Okazuje się bowiem, że to, co otwiera czy też ku czemu zmierza „mowa mówiąca”, obejmuje także mówiącego: jego ciało, egzystencję. Wyjątkowość i doniosłość aktu ekspresji - słowa-spontaniczności, jak nazywa ją w innym miejscu - polega na tym, że w niej właśnie egzystencja „polaryzuje się w pewien sens, którego nie można zdefiniować przez żaden przedmiot naturalny, bo egzystencja usiłuje dotrzeć do samej siebie ponad bytem”26. Próba wypełnienia pewnego braku ${ }^{27}$ - podjęcie twórczego mówienia, pisania - jest więc twórczością tyleż w znaczeniu potocznym (kreatywną aktywnością, której celem jest wytwór-rzecz o pewnej wartości), co twórczym sposobem kontaktu z bytem-światem, sposobem jego doświadczania (a więc sedymentacji sensu), ale również, jak notuje Merleau-Ponty w trybie niemal osobistego wyznania czy też swoistego confiteora, „synchroniczną modulacją mojej własnej egzystencji, przekształceniem mojego bycia”28. To, mówiąc inaczej, transcendowanie siebie ku nowemu zachowaniu, ku nowemu sposobowi bycia, ku nowej myśli, ale też: ku drugiemu człowiekowi.

Jeśli w przeżyciu ciała, w cielesnym doświadczeniu oraz geście jako akcie ekspresji zawiązuje się sens rzeczy, ku której wychyla się ciało, oraz sens egzystencji, której ciało jest wehikułem, to słowna ekspresja, twórczość, literatura - prócz tego, że bywa (najczęściej) reprezentacją rzeczy (i myśli), które już są zadomowione w kulturze, tworzą jej uniwersum ${ }^{29}$ - może być jednostkowym zdarzeniem (lub lepiej: doświadczeniem) o podobnym charakterze i przebiegu: stawaniem, stwarzaniem, wydobywaniem się podmiotu ${ }^{30}$. I to zarówno mówiącego-piszącego, jak i słuchającego-czytającego. Słowo bowiem „w chwili swych narodzin ustanawia wspólną sytuację, która jest nie tylko wspólnotą istnienia, ale również wspólnotą działania. Tu właśnie dochodzi naprawdę do komunikowania, tu milczenie zostaje przerwane»31. Na czym polega to działanie, które ma być istotą komunikacji? To

${ }^{24}$ M. Merleau-Ponty, Postrzeganie, ekspresja, sztuka, w: idem, Proza świata..., s. 212.

${ }_{25}$ M. Merleau-Ponty, Obecni w słowie, s. 79.

${ }^{26}$ M. Merleau-Ponty, Fenomenologia percepcji, s. 218.

27 „Każdy, kto mówi lub pisze, jest jakby dotknięty z początku niemotą”. M. Merleau-Ponty, Fantom czystego języka, w: idem, Proza świata..., s. 41.

${ }^{28}$ M. Merleau-Ponty, Fenomenologia percepcji, s. 215.

29 „Zwykły prozaik zadowala się sięganiem za pośrednictwem utartych znaków po znaczenia już utrwalone w kulturze”. M. Merleau-Ponty, Wyznanie wiary, s. 34.

${ }^{30}$ Podobną myśl można odnaleźć w rozważaniach Theodora W. Adorno: dzieło, będąc w akcie twórczym, w akcie ekspresji, stawaniem się piszącego podmiotu, istniejąc już - powtarza „to, w jaki sposób on się poczyna i wyłania”. Zob. Th.W. Adorno, Teoria estetyczna, tłum. K. Krzemieniowa, Wydawnictwo Naukowe PWN, Warszawa 1994, ss. 206-207.

${ }^{31}$ M. Merleau-Ponty, Obecni w słowie, s. 72. W innym zaś miejscu: „Mowa, gdy rodzi się i żyje, jest gestem ponawiającym i odzyskującym, który łączy mnie ze mną i innymi”. M. Mer- 
aktywne otwarcie na inność, ruch ku tej inności (i Innemu), która ma wypełnić pierwotny brak. Pisze Merleau-Ponty:

Jeśli książka naprawdę czegoś mnie uczy, jeśli ten drugi jest naprawdę kimś innym, musi w pewnej chwili mnie zaskoczyć, zdezorientować i musimy się spotkać ze sobą, nie jako podobni do siebie, lecz jako różni, a to zakłada jakieś przekształcenie zarówno mnie, jak tego drugiego; nasze różnice nie mogą już być nieprzezroczystymi jakościami, muszą się stać znaczeniami ${ }^{32}$.

I zdaniem tym wkracza w rejony opanowane przez filozofię dialogu. Jak blisko stąd do uwagi Emmanuela Lévinasa wypowiedzianej przy okazji charakterystyki pisarstwa Maurice’a Blanchota:

Wprowadzić sens w Byt to przejść od Tego Samego do Innego, od Ja do Drugiego Człowieka, to dać znak, zniweczyć struktury języka. Bez tego świat znałby jedynie znaczenia ożywiające protokoły bądź sprawozdania z zebrań zarządu Towarzystwa Anonimów ${ }^{33}$.

Niech wybrzmi to mocno: słowna ekspresja, twórczość, literatura - to spotkanie z innością i z innym, wydobywanie bądź sedymentacja sensu z bytu, zdarzenie stwarzające jednostkowość. Myśl tę w kolejnych dekadach podchwyciła teoria literatury, czyniąc z niej (mniej lub bardziej świadomie) drogowskaz dla poszukiwań nowych, niestrukturalistycznych, konceptualizacji przedmiotu swoich badań. Kilka przykładów: o lekturze dekonstrukcyjnej jako zdarzeniu tekstu (i właśnie lektury) pisał Jacques Derrida. Najkrócej rzecz ujmując: czytanie to odpowiadanie na zdarzenie dzieła, na każdorazową jednostkowość, idiomatyczność i niepowtarzalność utworu takim samym zdarzeniem - lekturą usytuowaną; to odpowiadanie imieniem własnym na imię własne dzieła ${ }^{34}$. Podobnym tropem podąża Derek Attridge, pisząc, że

[...] o literackości możemy mówić dopiero wtedy, gdy czytelnik (którym jest w pierwszej kolejności pisarz czytający lub wymawiający słowa w momencie ich pojawiania się) przeżywa to przekształcające zdarzenie jako zdarzenie, otwierające nowe możliwości znaczenia i odczuwania (rozumianych czasownikowo), albo mówiąc dokładniej, gdy przeżywa je jako takie otwarcie ${ }^{35}$.

leau-Ponty, Ekspresja w świetle doświadczenia i refleksji, tłum. J. Skoczylas, w: idem, Proza świata..., s. 125.

32 Ibidem, s. 75.

${ }^{33}$ E. Lévinas, Imiona własne, tłum. J. Margański, KR, Warszawa 2000, s. 163.

${ }^{34}$ „Jest to jakby pojedynek jednostkowości, pojedynek pisania i czytania, w toku którego kontrsygnatura zmierza zarówno do potwierdzenia, powtórzenia i uznania sygnatury innego, sygnatury oryginału, jak do wyprowadzenia jej gdzieś indziej, ryzykując jej zdradę, niejako zmuszona do zdrady pozwalającej na jej uznanie, poprzez wynalezienie innej, równie swoistej sygnatury”. J. Derrida, Ta dziwna instytucja zwana literaturq. Z Jacques'em Derridq rozmawia Derek Attridge, tłum. M.P. Markowski, „Literatura na Świecie” 1998, nr 11-12, s. 218.

${ }^{35}$ D. Attridge, Jednostkowość literatury, s. 90. 
To, rzecz jasna, otwarcie ku inności, ku takiemu myśleniu i odczuwaniu, które do tej pory było niemożliwe ${ }^{36}$ : „ten proces inicjacji, ruch w nieznane jest doświadczeniem czegoś, co zdarza się czytelnikowi w trakcie pełnej oddania i uważnej lektury [...] nierozdzielnej z aktem-zdarzeniem pisania”37. Wreszcie na gruncie polskiego literaturoznawstwa kwestie te stanowią centrum problemowe proponowanej przez Ryszarda Nycza poetyki doświadczenia. Pośród różnych konceptualizacji i charakterystyk owej „nierozerwalnej więzi doświadczenia z literaturą”38 można znaleźć tezę mówiącą, iż literatura nowoczesna jest literaturą doświadczenia - w jego nowoczesnych wariantach - a w jej obrębie da się wyróżnić kilka typowych dla nowoczesności praktyk czy też dominujących dyskursów literackich. Ma to być „literatura eksperymentalna”, „literatura przeżycia wewnętrznego”, „literatura świadectwa”, wreszcie - „literatura jako doświadczenie”. Ta ostatnia interesuje nas najbardziej. Inspirację dla swej propozycji wskazuje Nycz w jednej z późnych wypowiedzi Foucaulta - autor Słów i rzeczy w części swej twórczości chciał bowiem widzieć „książki-doświadczenia” lub też „dzieła-procesy”:

[...] procesy transformacji obejmujące jego jako piszącego, który stawał się kimś innym - w toku eksploracji nieznanego, terytoriów niedających się objąć żadną przewidywalną procedurą, metodą eksplanacyjnego wyjaśniania; oraz podobnie oddziałujące na czytelnika, który również, za sprawą ich lektury, miał sposobność doświadczyć na sobie takiej przemiany ${ }^{39}$.

„Literatura jako doświadczenie” ma obejmować szersze zjawisko ${ }^{40}$ (dzieło Foucaulta jest jego egzemplarycznym przypadkiem), które wcześniej, jak notuje Nycz, próbowali ująć w karby naukowego czy teoretycznego dyskursu tak różni myśliciele, jak: John Dewey, Martin Heidegger, Georges Bataille, Maurice Blan-

${ }^{36}$ Zdaniem tym nieuchronnie wkraczamy na teren antropologii literatury Wolfganga Isera, który funkcji wywodzącej się z mitu literatury upatruje w eksploracji obszarów nieuchwytnych, wymykających się systemom wyjaśniającym danej kultury oraz w dążeniu do transgresji. Zob. W. Iser, Czym jest antropologia literatury? Różnica między fikcjami wyjaśniajq̨cymi a odkrywajq̨cymi, tłum. A. Kowalcze-Pawlik, „Teksty Drugie” 2006, nr 5, ss. 11-35. Por. A. Łebkowska, Poznawanie siebie i poznawanie innego. Wobec inności literatury, „Przestrzenie Teorii” 2005, nr 5, ss. 9-26.

${ }^{37}$ D. Attridge, Jednostkowość literatury, s. 90.

${ }^{38}$ R. Nycz, Od teorii nowoczesnej do poetyki doświadczenia, w: idem, Poetyka doświadczenia. Teoria - nowoczesność - literatura, Instytut Badań Literackich PAN, Warszawa 2012, s. 149.

${ }^{39}$ R. Nycz, Literatura nowoczesna wobec doświadczenia, w: idem, Poetyka doświadczenia..., s. 223.

${ }^{40}$ Jego granice wyznaczają trzy punkty orientacyjne: po pierwsze, „,przeświadczenie, iż sztuka, literatura, poezja jest specyficzną (acz często negatywną) i faktyczną postacią doświadczania realności (a nie owego doświadczenia odtworzeniem, reprezentacją czy wtórnym utrwaleniem); po drugie, „dostrzeżenie ekwiwalencji w pozycji i charakterystyce podmiotu oraz tekstu/dzieła sztuki w relacjach ze światem”; po trzecie, „uznanie, iż nieuchronna dyskursywizacja doświadczenia nie oznacza koniecznie wykluczenia czy stłumienia jego zmysłowych, bezrefleksyjnych i bezznaczeniowych wymiarów”, które „osadzone czy zaszyfrowane w nieświadomości tekstu [...] podlegają reaktywacji w doświadczeniu czytelnika”. Ibidem, ss. 223-224. 
chot, Roland Barthes, Jacques Derrida, Julia Kristeva, Jean-Luc Nancy czy Philippe Lacoue-Labarthe.

Tak, brak na tej liście nazwiska Merleau-Ponty’ego. Powodem nie jest raczej to, że nie pisał o literaturze, lub że nie wiązał jej z doświadczeniem. Czynił to nader często - nadawał ekspresji słownej cech samego doświadczenia, w którym to, co myślowo-dyskursywne, zestraja się z tym, co cielesne i sytuacyjne, w którym moment epistemiczny wynika ze sposobu bycia i działania, ekspresji - dzieła oraz jego podmiotu. Dowodem tego przywoływany tu po wielokroć tom esejów o mowie oraz liczne uwagi o roli i randze twórczości, sztuki, literatury tak dla bycia, jak i poznania - rozsiane po całym jego œuvre. Zacytuję jeszcze jeden fragment - z Widzialnego i niewidzialnego, jego ostatniej, nieukończonej za życia pracy (wydanej z rękopisów w trzy lata po śmierci autora). Splot doświadczenia i twórczości zyskuje tu jeszcze jedno ujęcie:

Filozofia właśnie jako „Byt mówiący w nas”, jako sama z siebie wydobywająca się ekspresja milczącego doświadczenia, jest twórczością. Twórczością, która jest zarazem reintegracją Bytu: nie jest bowiem twórczością w sensie któregoś z Gebilde, wyłanianego przez historię: rozpoznaje ona siebie jako Gebilde i jako czyste Gebilde pragnie siebie przekroczyć, pragnie odnaleźć swoje źródło. Jest ona zatem twórczością w sensie radykalnym: twórczością, która równocześnie jest adekwacją, jedynym sposobem uzyskania adekwacji. To pogłębia znacznie poglądy Souriau na filozofię jako najwyższą sztukę: bowiem i sztuka i filozofia wzięte razem z pewnością nie są dowolnymi produktami duchowego „uniwersum” („kultury”), lecz kontaktem z Bytem właśnie jako kreacje. Po to, aby go doświadczać, Byt wymaga od nas twórczości ${ }^{41}$.

Mniejsza jednak o powody tej nieobecności. Nie o pedantyczną skrupulatność we wskazywaniu możliwych antecedencji tej konkretnej propozycji tu idzie. Kusi co innego. Mianowicie: by podjąć ryzyko wykonania gestu - gestu szczególnego, językowego - który wychodząc od zaproponowanego przez filozofa rozumienia ciała, wskazywałby (zaledwie wskazywał) w literaturze obszar (pozwólmy sobie na moment mowy niedyskursywnej)... zamieszkiwany właśnie przez ciała. Ciała piszące, pisane i czytające. Terytorium to - niejednorodne, niespójne, rozczłonkowane na enklawy pojedynczych dzieł, pisarskich projektów i ich realizacji - nie jest regulowane rozporządzeniami klasycznej poetyki; nie daje się objąć i zamknąć w granicach określonej techniki pisarskiej, gatunku, rodzaju a nawet jednego wyłącznie medium. Mowa bowiem o literaturze-geście ${ }^{42}$ powołującym (do istnienia,

${ }^{41}$ M. Merleau-Ponty, Widzialne i niewidzialne, tłum. zbiorowe, oprac. J. Migasiński, Fundacja Aletheia, Warszawa 1996, s. 200.

${ }^{42}$ Tego „gestowego” czy „performatywnego” aspektu nie sposób sprowadzić wyłącznie do - podejmowanej przez ukształtowane na strukturalistycznym paradygmacie literaturoznawstwo - problematyki dzieła jako faktu społecznego, sposobu kontaktu twórcy z publicznością czy czynu społecznego, który oddziałuje kształtująco na świadomość odbiorców: poszerza horyzonty poznawcze, formuje światopogląd, utrwala wzorce moralne, kształtuje zapatrywania ideowe (zob. M. Głowiński, A. Okopień-Sławińska, J. Sławiński, Zarys teorii literatury, Wy- 
stawania się) ciało (w jego wymiarach: fizyczno-sensualnym, dziejowo-sytuacyjnym $^{43}$, ale także w jego geście wychylenia ku inności ${ }^{44}$, Innemu jako potencjalności sensu) w pisaniu i czytaniu. Mowa o wcale niemałej liczbie dzieł, które rozgrywają się w planie podmiotowego stawania się, wydobywania, bycia i trudno uchwytnej obecności ${ }^{45}$. Które są bądź chcą być - by posłużyć się sformułowaniem Merleau-Ponty’ego - interwencją w byt oraz jego reintegracją, nadto reintegracją bycia w relacjach ze światem, z innymi, a czasem też i instauracją oraz uobecnieniem bycia... w tym właśnie „geście ponawiającym i odzyskującym, który łączy mnie ze mną i innymi”"46, w mowie.

Nieco ciemną tę myśl - zdaję sobie z tego sprawę - rozświetlić może instruktywny przykład tak rozumianej literatury-gestu oraz jego - pobieżne z konieczności - przybliżenie.

\section{4.}

„Brak historii (w planie fikcji) rodzi gęstość historii (w planie pisania)”47, zanotował ongiś Roland Barthes. Pisał o twórczości Philippe’a Sollersa, ale zdaniu temu można by przypisać wiele adresów. Jednym z nich jest proza Stanisława Czycza, długo nieobecnego w powszechnej świadomości literackiej i na kartach historii literatury polskiej, od pewnego jednak czasu zyskującego zainteresowanie i uznanie - tak czytelników, jak badaczy dostrzegających w nim ważną postać polskiej literatury nowoczesnej. Przyczyn tej nieobecności (zwłaszcza w obiegu czytelniczym) można by upatrywać w wysokich wymaganiach, jakie stawia ta twórczość swoim

dawnictwa Szkolne i Pedagogiczne, Warszawa 1986). Ów cielesny gest nie jest też wyłącznie kwestią krytyki somatycznej Adama Dziadka, którego projekt zgrabnie przybliża Ryszard K. Przybylski w recenzji wydawniczej książki katowickiego badacza: „nie tylko lokuje akt pisania/ czytania w porządku doświadczeń zmysłowych, ale również samemu tekstowi literackiemu [...] przyporządkowuje ciało”. Zob. A. Dziadek, Projekt krytyki somatycznej, Wydawnictwo Instytutu Badań Literackich PAN, Warszawa 2014.

${ }^{43} \mathrm{~W}$ rozumieniu hermeneutyki nowoczesnej.

${ }^{44}$ Którą może być choćby - wedle słów Paula Ricoeura - doświadczanie własnego ciała. Zob. P. Ricoeur, O sobie samym jako innym, tłum. B. Chełstowski, Wydawnictwo Naukowe PWN, Warszawa 2003, s. 529.

${ }^{45} \mathrm{~W}$ innym miejscu tę złożoną problematykę podmiotowej obecności w tekście i wobec tekstu próbowałem ująć za pomocą kategorii głosu, która obejmowała zjawisko samego komunikowania, samego kontaktu, którego przejawem jest to wszystko, co dokonuje się w tekście i poprzez tekst, na każdej jego płaszczyźnie formalnej i treściowej. Głos, pisałem, powołuje do życia sama scena pisania, jest on funkcją tej sceny, efektem czystej produktywności pisania. Zob. T. Gruszczyk, Ocalajq̨ce zatracenie. Rozważania o doświadczeniu, pamięci i pragnieniu w twórczości Zygmunta Haupta, Stanisława Czycza i Krzysztofa Vargi, Wydawnictwo Uniwersytetu Śląskiego, Katowice 2018.

${ }^{46}$ M. Merleau-Ponty, Ekspresja w świetle doświadczenia..., s. 125.

${ }^{47}$ R. Barthes, Dramat, poemat, powieść, tłum. K. Kłosiński, w: idem, Lektury, wybór, oprac. i posłowie M.P. Markowski, Wydawnictwo KR, Warszawa 2001, s. 29. 
odbiorcom. W nieschlebianiu pospolitym gustom, w ostentacyjnej niechęci do zaspokajania typowych czytelniczych potrzeb: oryginalnej historii, dobrze skrojonej i zajmującej fabuły, wyrazistych bohaterów wikłających się w niebanalne wypadki o decydującym znaczeniu dla ich losów. W tej prozie bowiem, w jej planie fabuły, historii, albo wszystko już się wydarzyło, albo jeszcze nie wydarzyło, ale też już nie wydarzy. Nawet jeśli w niektórych „opowiadaniach krzeszowickich”48 sięga Czycz po schematy i konwencje literatury popularnej, przygodowej, podróżniczej, to czyni to, by z nich kpić i by pokazać brak: brak Przygody, brak Sensacji, brak Wydarzenia. Pisałem już w innym miejscu ${ }^{49}$, że banalne historyjki, w których autor każe uczestniczyć swoim bohaterom, można czytać jako stawiane przed nimi proste zadania i ćwiczenia mające ich doprowadzić do mistrzostwa w dyscyplinie nie-osiągania-niczego. Na dowód - trzy krótkie przykłady.

W Górach słabo widocznych Mikado i Traper wyruszają w wigilię Bożego Narodzenia w stronę pobliskich gór, by, po pierwsze, przekonać się, „czy to są już jakieś prawdziwe góry czy tylko pagórki podobne do tego w naszym lesie a tylko trochę większe" ${ }^{50}$, po wtóre, by stamtąd ujrzeć w całej okazałości upragnione Tatry. Chłopcy brodzą w zaspach, w zadymce, w leśnych ciemnościach. Gdy wyrasta przed nimi wieża triangulacyjna, wspinają się niemal na sam jej szczyt, by zorientować się w swym położeniu. Mikado nie wypatruje jednak w zamieci dalekich gór, lecz domu, Miasteczka:

- Widziałeś? - zapytał mnie Traper.

- Widziałem... - odpowiedziałem niepewnie bo on pytał mnie chyba o góry a ja żadnych gór nie widziałem, jeżeli patrzyłem w tak zwane dale to w kierunku akurat odwrotnym - jak też daleko jesteśmy od domu - ale tam nie było widać nic prócz pól i paru bliższych lasów i zadymki ${ }^{51}$.

I rzeczywiście, chłopcy gór już nie zobaczą. Zdobędą co prawda jakiś szczyt, którego potem, w drodze powrotnej, nie będą umieli zlokalizować, stracą z oczu wieżę triangulacyjną oraz sterczące wysoko ponad innymi drzewo, „baobab”, pełniące funkcje punktów orientacyjnych, na koniec zaś, późnym wieczorem, jak im się będzie zdawało, pogubią się już całkowicie, a pogoda zmusi ich do rozbicia obozu, rozpalenia ogniska, ogrzania się. Po mozolnych, długich próbach zagotowania wody na herbatę zorientują się, że marzną na granicy lasu przylegającego do Miasteczka, dwieście metrów od domu Trapera.

${ }^{48}$ Chodzi o utwory z dwóch tomów Czycza - Nim zajdzie księżyc z 1968 roku oraz Nie wiem co ci powiedzieć z roku 1983 - których „akcja” rozgrywa się w Miasteczku, zwanym też Sorrento, którym są rodzinne Krzeszowice autora. Po latach (w 2016 roku) utwory te złożyły się na tom zatytułowany Opowiadania krzeszowickie właśnie.

${ }^{49}$ Zob. T. Gruszczyk, Ocalajq̨ce zatracenie... Korzystam tutaj z ustaleń tam poczynionych, niemniej służą mi one do zaprezentowania tej twórczości w innym nieco świetle.

${ }^{50}$ S. Czycz, Góry słabo widoczne, w: idem, Nim zajdzie księżyc, Wydawnictwo Literackie, Kraków 1968, s. 86.

51 Ibidem, s. 91. 
Tymi samymi współrzędnymi przebiega nocna wyprawa Mikady i Primavery, chcących dojść do Wisły, mającej przepływać dwadzieścia kilometrów od Miasteczka:

Krótko mówiąc, mieliśmy wytknięty pewien konkretny cel, i chcieliśmy go osiągnąć idąc lasami, „dzikimi lasami”, [...] i idąc nocą [...] $]^{52}$.

Nad ranem, po pokonaniu kilkunastu strumyków i rzeczułek, po rozwieszeniu między gałęziami płachty udającej namiot, po ulewnej burzy, bohaterowie budzą się tuż przy lokalnej drodze, wychodzą na najbliższe wzniesienie po to tylko, by stwierdzić, że w nocy pobłądzili i krążąc wokół Miasteczka kilkanaście razy pokonywali ten sam strumyk. Primavera ze zdziwieniem stwierdza:

- Jesteśmy teraz prawie w tym samym miejscu, w którym wczoraj weszliśmy w las. A szliśmy przecież w jednym kierunku, na południe ${ }^{53}$.

Bohaterowie-podróżnicy wracają do punktu wyjścia i nawet planują podjęcie drugiej próby dotarcia nad Wisłę albo chociaż po nóż pozostawiony w lesie, ale, jak można się domyśleć w zakończeniu utworu, wyprawa nigdy nie dojdzie do skutku. Podobnie przedstawia się sytuacja w Górach słabo widocznych - Mikado i Traper ich nie tylko nie zdobyli, ale nawet nie zobaczyli. Mikadę w całej wyprawie najbardziej intryguje sprawa „baobabu”:

[...] gdy chciałem tam kiedyś jeszcze iść to głównie żeby zobaczyć jego [...] tak mi jakoś stał w pamięci, widziałem te jego wielkie płowe konary tam wzniesione wysoko ponad lasem, i jeszcze długo myślałem że on tam może jeszcze jest i że zobaczę go na pewno gdy tam pójdę i że tym razem odnajdę go w tym lesie popatrzę na niego z bliska ${ }^{54}$.

Czas przeszły, w jakim mówi się o projektowanej wyprawie, każe o niej myśleć w kategoriach niezrealizowanej możliwości.

Wreszcie w najbardziej bodaj znanym, debiutanckim utworze prozatorskim Czycza zatytułowanym And, narrator-bohater postanawia zostać poetą. W tym celu na zebraniu Koła Młodych Związku Literatów przedstawia wiersze, które odnalazł w walizce. Występek młodego adepta sztuki uznano za oburzający, prowokacyjny i cyniczny. Niemniej do Koła Młodych zostaje przyjęty i wraz z nowym przyjacielem, młodym, ale już uznanym poetą, tytułowym Andem, wyrusza na Festiwal Zaczynających Pisać i Zapowiadających się. Tam zaś czynią oni wszystko, by nie być tym, kim są inni, by nie wpisywać się w model Poety. Ich występowanie na festiwalu dla młodych twórców to w istocie występowanie z festiwalu i życia literackiego. Trzydniowe spotkanie wypełniają im zajęcia niewiele związane z Wydarzeniem: grają nieustannie w karty (w pokera, w oko, wreszcie w wojnę), śpiewają W krzyżu cier-

52 S. Czycz, Nad rzekq, której nie ma, w: idem, Nim zajdzie księżyc, s. 58.

53 Ibidem, s. 66.

${ }^{54}$ S. Czycz, Góry słabo widoczne, ss. 106-107. 
pienie, rozglądają się za „dziwami” i - przede wszystkim - piją. Jeśli już opuszczają pokój hotelowy, to po to tylko, by prowadzić cyniczną grę z jego organizatorami i uczestnikami, grę obliczoną na skompromitowanie tych, którymi gardzą.

Pisarstwo to zasilane jest w dużej mierze biografią autora - historia opowiedziana w Andzie rzeczywiście miała miejsce i jest typowym przykładem literackiego skandalu: w 1954 roku 25-letni Stanisław Czycz, pracownik kamieniołomów w Krzeszowicach, absolwent technikum elektrycznego, przedłożył w krakowskim oddziale Związku Literatów Polskich zestaw wierszy. Chciał, by zostały wydrukowane, a on przyjęty do Koła Młodych. Wiersze, w większości, nie były jego autorstwa: znalazł je w domu kolegi, w walizce, na strychu. Do tej pory nie miał żadnej styczności z literaturą, z poezją, nie mógł więc wiedzieć, że to Głosy biednych ludzi Czesława Miłosza.

To najbardziej znany, bo i jedyny eksces w życiu krzeszowicko-krakowskiego pisarza (co w istocie czyni z niego jednego z wielu pisarzy bez biografii). Ale nawet i on, przetworzony literacko, nie staje się kołem zamachowym dla rozbudowanej fabuły, lecz zaledwie pretekstem, punktem wyjścia do rozważań nad mową, pisaniem, literaturą. Nie jest więc pisarstwo Czycza projektem autobiograficznym czy autograficznym - mimo owej styczności czy nawet nieraz tożsamości podmiotu życia i podmiotu literackiego (na różnych poziomach instancji nadawczych). Acz samozwrotność, która zawiera się w przedrostku „auto”, można uznać za jej główny wyróżnik. Bo mamy w niej do czynienia z autointertekstualnością (autoaluzją, autocytatem), autorepetycją (powracaniem w całej twórczości pewnych osób, zdarzeń, sytuacji, sekwencji tekstowych) i - nade wszystko - swoistą autokreacją. Tyle tylko, że tej ostatniej nie można sprowadzać wyłącznie do wstecznego redagowania własnej przeszłości i projektowania własnego wizerunku w tekst i poza tekst ${ }^{55}$, lecz należy o niej myśleć jak o procedurze, akcie czy też zdarzeniu stawania się sobą, wydobywania siebie w działaniach komunikacyjnych, w mowie i pisaniu.

Jest to zatem pisarstwo autoteleologiczne, które rozgrywa się w napięciu między brakiem, nieobecnością a nadmiarem, nadobecnością - odpowiednio: historii, wydarzeń, fabuły oraz mowy i pisania. Tym, co spaja, łączy te dwa bieguny, jest ciało. Gdyby więc koniecznie chcieć mówić o jakichś przygodach w tej prozie, byłyby to przygody ciała i mówienia/pisania.

\section{5.}

Ciało w twórczości Czycza obecne jest na kilka sposobów. Przede wszystkim cielesność i jej przeżywanie bywają tu narracyjnie tematyzowane. Ciało ukazywane jest w działaniu, w mikrozdarzeniach, zalążkach sytuacji, wreszcie doświadczane w aktach percepcji, w samoobserwacji, której dokonuje narrator-bohater. Ale,

${ }_{55}$ Zob. M. Wołk, Autografia i powtórzenie, „Zagadnienia Rodzajów Literackich” 2014, nr LVII, z. 2. 
trzeba dopowiedzieć, nie jest to zawsze to samo ciało. Precyzyjniej: pojawia się ono na kartach tej prozy w różnych modalnościach, w zależności od funkcji, jaką pełni. Jest więc i ciało zmysłowe, i fizjologiczne, i emocjonalne, i społeczne. Zawsze jednak pozostaje ono bądź pragnie pozostać niepochwytne w przypisane mu zawczasu przez kulturę znaczenia.

W Nie wierz nikomu, ostatnim utworze wydanym za życia ${ }^{56}$, Czycz, sięgając do własnej biografii, opowiada historię młodzieńca, absolwenta technikum, który wkracza w dorosłe życie: podejmuje pierwszą pracę (w Krakowskich Zakładach Kamienia Budowlanego), po raz pierwszy się zakochuje, oczekuje upragnionej inicjacji seksualnej, wystawia się na spojrzenia innych, co zmusza go do podjęcia określonych ról społecznych (pracownika socjalistycznego zakładu, podwładnego, kolegi, współpracownika, specjalisty, przedstawiciela klasy robotniczej, kawalera z ambicjami i planami na przyszłość itd.) oraz przywdziewania masek. Im bardziej angażuje się w to nowe życie, tym wyraźniej dostrzega jednak, że zrywa w nim kontakt z samym sobą:

[...] oddala mnie ta praca od samego mnie... już nie że od marzeń... czy pragnień... pożegnanych przecież wcześniej... [...] ale że oddala mnie ode mnie, jakim byłem, i staję się... kim?... [...] i staję się kimś obcym mi... co byłoby może i ciekawe... [...] lecz ten nowy był dla mnie takim... że... [...] lecz ten inny, którym się stawałem, był dla mnie taki że nie potrafiłbym nim nie pogardzać,

nie że ten ja dotychczasowy był mi jakiś drogi, nie było mi drogie to wszystko moje i chciałem zapomniećs7

Dlatego będzie próbował od tego życia się oddzielić, odseparować - zrezygnuje z relacji międzyludzkich, zrezygnuje z miłości. Pozostanie mu doświadczanie niemal czysto biologicznego trwania, bez znaczenia i bez celu. Ale nie jako podmiot egzystencji, lecz jej przedmiot ${ }^{58}$ :

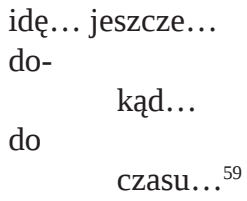

Z podobną modalnością bycia mamy do czynienia w opowiadaniu Ajil, pochodzącym z debiutanckiego tomu prozy Ajol. Narrator-bohater zamknięty w czterech ścianach ciasnego pokoju podejmuje się wysiłku przypomnienia i wypowiedzenia swej dawnej przygody miłosnej. Chce z niej uformować tekst: „gdyby z tej histo-

${ }^{56}$ Pierwsze wydanie miało miejsce w 1987 roku.

57 S. Czycz, Nie wierz nikomu, Korporacja Ha!art, Kraków 2016, ss. 191, 192, 195.

${ }^{58}$ Nawet spełnienie erotyczne dokona się nie za sprawą upragnionej Leny, lecz przypadkowej bufetowej z małej stacyjki kolejowej.

${ }^{59}$ Ibidem, s. 359. 
ryjki jakieś wzruszające opowiadanie była ładna i zakończenie ciekawe zacząłem

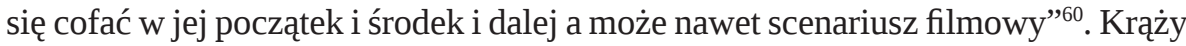
dniami i nocami po pokoju, nasłuchuje odgłosów świata zewnętrznego (bicie zegara na wieży, szum tramwajów) i notuje - na kartkach i ścianie przy łóżku - wszystkie swoje postrzeżenia: cielesne, zmysłowe, intelektualne, pamięciowe, wyobrażeniowe. Prowadzi go to do dwóch odkryć. Po pierwsze, dostrzega, że jego mowa zarażona jest cudzym słowem, że w żywej tkance indywidualnej ekspresji tkwią martwe komórki tradycji i literackich intertekstów, „mowy mówionej”: „, i większość tych słów, tych i przedtem i jeszcze gdy będą, a ty nie wiesz które, dyktują ci hypnotyzerzy"61. Drugie odkrycie wiąże się ze spojrzeniem w lustro, w którym żywe ciało zarażone jest już śmiercią: „to, to włosy, potworne, coś martwe wrośnięte w moją głowę tak silnie nie mogę zerwać utkwione w żywym, od początku życie tu tak dotykalnie wychylało się w martwe w śmierć, to strzygłeś czesałeś śmierć tak długo”62. Odbicie w lustrze, przeglądanie się w nim i przeżycie cielesności w dwojaki sposób (jako zagrożenia dla tożsamości oraz jako potworności w funkcji wskazywania pewnej potencjalności ${ }^{63}$ ) tak wskazuje pewną analogię, jak prowadzi do zrównania, utożsamienia - mówienia/pisania oraz ciała. Ciało przegląda się w lustrze na ścianie; mowa przegląda się w lustrze powstającego tekstu. Tak jak przycina się włosy i paznokcie, tak trzeba też będzie zadbać o tekst: „pamiętaj że to są tylko takie notatki do rozwinięcia i usuniesz wszystko co się tu wepchnęło niepotrzebnie”64. Jedno i drugie może być gwarantem jednostkowości, podmiotowej obecności, ale zarówno ciało, jak i mowa wystawione są na zagrożenia pochodzące z zewnątrz - ze strony biologii i kultury. „Strach przed pułapką literackiej formy wiąże się tu z nieufnością wobec odczłowieczających rytuałów świata pozaliterackiego”65, zanotował Jacek Rozmus.

Jest i trzecie odkrycie, jakie dokonuje się w Ajilu. Przypada ono w udziale czytelnikowi. Oto bowiem mocą metaleptycznej transgresji w tekście uobecnia się sam Czycz, jego ciało, jego gest: śledzenie mowy narratora-bohatera pozwala „śledzić sytuację, w jakiej powstawał znany z literackich czasopism, umieszczony w Tłach liryk Marzenie miłosne. [...] W rozwijającej się tym sposobem sytuacji intertekstualnego wywodu referowane zostają także wydarzenia, które zainspirowały wydany siedem lat przed Ajolem drugi tomik poezji Berenais”66. Można to powiedzieć też inaczej: w ekspresyjnym geście narratora-bohatera ujawnia się gest twórczy ciała rzeczywistego, który odsyła do dzieł istniejących w świecie pozatekstowym. Jeśli

60 S. Czycz, Ajil, w: idem, Ajol, Wydawnictwo Literackie, Kraków 1967, s. 88.

61 Ibidem, s. 109.

62 Ibidem, s. 129.

63 Pisałem o tym szerzej w swej książce: Ocalające zatracenie...

64 S. Czycz, Ajil, s. 91.

65 J. Rozmus, W okolicach arkadii Stanisława Czycza, Wydawnictwo Naukowe Akademii Pedagogicznej, Kraków 2002, s. 17.

66 J. Rozmus, Odkryć świat, wrócić do Sorrento, „Ha!art” 2001, nr 9-10, s. 27. 
nie dochodzi tu do stopienia, całkowitego zespolenia ekstratekstualnego podmiotu-ciała z podmiotami tekstowymi (na różnych poziomach instancji nadawczych) ${ }^{67}$, to granica między nimi jest bardzo cienka i sprowadza się do powierzchni lustra.

Ciało w Ajilu jest nie tylko narracyjnie tematyzowane, jest też figurą samego utworu jako komunikatu, w którym i poprzez który ustanawia się jakieś zindywidualizowane Ja. Innymi słowy, w Ajilu podejmuje się próbę nie tylko przedstawienia ciała, nie tylko jego wyrażenia, wyartykułowania czy zamanifestowania, lecz uobecnienia i usensownienia.

Ajil ma być monstrualnym polem niesemiotyzowalnych wrażeń, „słów istniejących w sferze doznań nieprzekładalnych na adekwatny wobec nich komunikat językowy”68. Ma być monstrualny w znaczeniu: wiecznie niegotowy, wskazujący, zapowiadający i ostrzegający. Jak ciało, któremu przygląda się bohater w lustrze.

Jeśli w Ajilu przegląda się Czycz, to wizerunek ten należy interpretować tyleż autobiograficznie czy autotematycznie, co autoteleologicznie. Bohater Nie wierz nikomu nie był jeszcze zdolny do twórczości, oddzielał się od siebie zawładnięty mową mówioną. Piszący w Ajilu i piszący Ajila (bo piszący Tła oraz, jak wskazuję gdzie indziej, późniejsze opowiadania krzeszowickie ${ }^{69}$ ),,zaszczepia sens tam, gdzie go nie było”, wykonuje „gest ponawiający i odzyskujący” - to ciało, tę egzystencję - „który łączy mnie ze mną i innymi”.

Usensownianie świata, nazywanie go, odkrywanie ${ }^{70}$, które dokonuje się w twórczej mowie i pisaniu to nadawanie sensu i celu własnemu ciału-egzystencji: chodzi przecież o to, by nie poddać się ujarzmiającej mocy kulturowych dyskursów, konwencji i znaczeń. By nie dać się (siebie - ciała i mowy) sprowadzić do - choćby nabrzmiałego pełnią znaczenia - znaku, który zamyka, zawłaszcza i wywłaszcza.

\section{Literatura}

Abram D., The Spell of the Sensuous: Perception and Language in a More-than Human World, Pantheon Books, New York 1996.

Adorno Th.W., Teoria estetyczna, tłum. K. Krzemieniowa, Wydawnictwo Naukowe PWN, Warszawa 1994.

Attridge D., Jednostkowość literatury, tłum. P. Mościcki, Towarzystwo Autorów i Wydawców Prac Naukowych Universitas, Kraków 2007.

67 „Akt pisania polegać ma na ciągłym niedotrzymywaniu umowy zakładającej autonomię dwu rzeczywistości: realnej i literackiej”. J. Rozmus, W okolicach arkadii Stanisława Czycza, s. 29.

${ }^{68}$ H. Zaworska, „...A wszystko jest rozpadanie”, „Twórczość” 1968, nr 2, s. 192.

${ }^{69}$ Zob. T. Gruszczyk, Ocalajq̨ce zatracenie...

${ }^{70}$ Ćwiartowanie historii, zszywanie w obrębie poszczególnych niby-zdań tego wszystkiego, co pamiętane i wyobrażane z tym, co doznawane i przeżywane w trakcie pisania przez narratora-bohatera, deregulacja systemu poprawności językowej, składni, zaburzenia logiki wypowiedzi wszystko to przynosi erupcję nieoczekiwanych, „nieomówionych” sensów. 
Barthes R., Dramat, poemat, powieść, tłum. K. Kłosiński, w: idem, Lektury, wybór, oprac. i posłowie M.P. Markowski, KR, Warszawa 2001.

Casanova P., Światowa republika literatury, tłum E. Gałuszka, A. Turczyn, Wydawnictwo Uniwersytetu Jagiellońskiego, Kraków 2017.

Cichowicz S., Poezja świata, w: M. Merleau-Ponty, Proza świata. Eseje o mowie, Czytelnik, Warszawa 1976.

Coetzee J.M., Doubling the Point: Essays and Interviews, red. D. Attwell, Harvard University Press, Cambridge 1992.

Czycz S., Ajil, w: idem, Ajol, Wydawnictwo Literackie, Kraków 1967.

Czycz S., Góry słabo widoczne, w: idem, Nim zajdzie księżyc, Wydawnictwo Literackie, Kraków 1968.

Czycz S., Nad rzekq, której nie ma, w: idem, Nim zajdzie księżyc, Wydawnictwo Literackie, Kraków 1968.

Czycz S., Nie wierz nikomu, Korporacja Ha!art, Kraków 2016.

Derrida J., Ta dziwna instytucja zwana literaturq. Z Jacques'em Derridq rozmawia Derek Attridge, tłum. M.P. Markowski, „Literatura na Świecie” 1998, nr 11-12.

Drwięga M., O działaniu i relacji dusza-ciało w filozofii Maurice’a Merleau-Ponty'ego w pięćdziesiq̨tq rocznicę śmierci, „Kwartalnik Filozoficzny” 2011, t. XXXIX, z. 3.

Dziadek A., Projekt krytyki somatycznej, Wydawnictwo Instytutu Badań Literackich PAN, Warszawa 2014.

Głowiński M., Okopień-Sławińska A., Sławiński J., Zarys teorii literatury, Wydawnictwa Szkolne i Pedagogiczne, Warszawa 1986.

Gołębiewska M., Sensotwórcza rola ciała w samopoznaniu według Maurice’a Merleau-Ponty'ego, „Teksty Drugie” 2004, nr 1-2.

Grosz E., Volatile Bodies: Toward a Corporeal Feminism, Indiana University Press, Bloomington 1994.

Gruszczyk T., Ocalajq̨ce zatracenie. Rozważania o doświadczeniu, pamięci i pragnieniu w twórczości Zygmunta Haupta, Stanisława Czycza i Krzysztofa Vargi, Wydawnictwo Uniwersytetu Śląskiego, Katowice 2018.

Gurczyńska-Sady K., Człowiek jako słowo i ciało. W poszukiwaniu nowej koncepcji podmiotu, Towarzystwo Autorów i Wydawców Prac Naukowych Universitas, Kraków 2013.

Husserl E., Idee czystej fenomenologii i fenomenologicznej filozofii, t. II, tłum. D. Gierulanka, PWN, Warszawa 1974.

Hyży E., Kobieta, ciało, tożsamość. Teorie podmiotu w filozofii feministycznej końca XX wieku, Towarzystwo Autorów i Wydawców Prac Naukowych Universitas, Kraków 2003.

Iser W., Czym jest antropologia literatury? Różnica między fikcjami wyjaśniającymi a odkrywającymi, tłum. A. Kowalcze-Pawlik, „Teksty Drugie” 2006, nr 5.

Kwietniewska M., Maurice Merleau-Ponty: u zarania filozofii różnicy we Francji, „Hybris” 2016, nr 34.

Lévinas E., Imiona własne, tłum. J. Margański, KR, Warszawa 2000.

Łebkowska A., Poznawanie siebie i poznawanie innego. Wobec inności literatury, „Przestrzenie Teorii" 2005, nr 5.

Łebkowska A., Somatopoetyka, w: Kulturowa teoria literatury 2. Poetyki, problematyki, interpretacje, red. T. Walas, R. Nycz, Towarzystwo Autorów i Wydawców Prac Naukowych Universitas, Kraków 2012. 
Maciejczak M., Świat według ciała w Fenomenologii percepcji Merleau-Ponty’ego, Wydawnictwo IFiS PAN, Warszawa 2001.

Merleau-Ponty M., Ekspresja w świetle doświadczenia i refleksji, tłum. J. Skoczylas, w: idem, Proza świata. Eseje o mowie, Czytelnik, Warszawa 1976.

Merleau-Ponty M., Fantom czystego języka, tłum. S. Cichowicz, w: idem, Proza świata. Eseje o mowie, Czytelnik, Warszawa 1976.

Merleau-Ponty M., Fenomenologia percepcji, tłum. M. Kowalska i J. Migasiński, posł. J. Migasiński, Fundacja Aletheia, Warszawa 2001.

Merleau-Ponty M., Obecni w słowie, tłum. J. Skoczylas, w: idem, Proza świata. Eseje o mowie, Czytelnik, Warszawa 1976.

Merleau-Ponty M., Postrzeganie, ekspresja, sztuka, tłum. E. Bieńkowska, w: idem, Proza świata. Eseje o mowie, Czytelnik, Warszawa 1976.

Merleau-Ponty M., Widzialne i niewidzialne, tłum. zbiorowe, oprac. J. Migasiński, Fundacja Aletheia, Warszawa 1996.

Merleau-Ponty M., Wyznanie wiary, tłum. S. Cichowicz, w: idem, Proza świata. Eseje o mowie, Czytelnik, Warszawa 1976.

Migasiński J., Merleau-Ponty, Wiedza Powszechna, Warszawa 1995.

Nycz R., Literatura nowoczesna wobec doświadczenia, w: idem, Poetyka doświadczenia. Teoria - nowoczesność - literatura, Instytut Badań Literackich PAN, Warszawa 2012.

Nycz R., Od teorii nowoczesnej do poetyki doświadczenia, w: idem, Poetyka doświadczenia. Teoria - nowoczesność - literatura, Instytut Badań Literackich PAN, Warszawa 2012.

Pokropski M., Ciało. Od fenomenologii do kognitywistyki, „Przegląd Filozoficzno-Literacki” 2011, nr 4

Ricoeur P., O sobie samym jako innym, tłum. B. Chełstowski, Wydawnictwo Naukowe PWN, Warszawa 2003.

Rozmus J., Odkryć świat, wrócić do Sorrento, „Ha!art” 2001, nr 9-10.

Rozmus J., W okolicach arkadii Stanisława Czycza, Wydawnictwo Naukowe Akademii Pedagogicznej, Kraków 2002.

Wołk M., Autografia i powtórzenie, „Zagadnienia Rodzajów Literackich” 2014, nr LVII, z. 2.

Zaworska H., „...A wszystko jest rozpadanie”, „Twórczość” 1968, nr 2. 
